\title{
Evidence that glucagon stimulates insulin secretion through its own receptor in rats
}

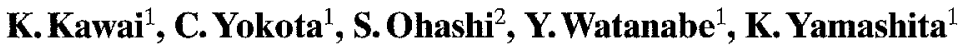 \\ ${ }^{1}$ Department of Internal Medicine, Institute of Clinical Medicine, University of Tsukuba, Tsukuba, Japan \\ ${ }^{2}$ National Institute of Bioscience and Human Technology, Tsukuba, Japan
}

Summary Since glucagon-like peptide-1 (7-36) amide (7-37) (GLP-1) has been found to be a potent insulinotropic hormone, it has been postulated that glucagon stimulates insulin secretion from islet beta cells through the GLP-1 receptor. We therefore examined the effects of a GLP-1 receptor antagonist, exendin (9-39) amide, on glucagon- or GLP-1-stimulated insulin release from isolated perfused rat pancreas. When infusion of $100 \mathrm{nmol} / \mathrm{l}$ exendin (9-39) amide was started $5 \mathrm{~min}$ before that of $1 \mathrm{nmol} / 1$ glucagon, the stimulation of insulin release by glucagon was similar to that found in the control situation (preinfusion with vehicle alone). By contrast, when $0.3 \mathrm{nmol} / \mathrm{l} \mathrm{GLP}-1$ was used in the same experimental setting, exendin (9-39) amide clearly inhibited insulin release. These results indicate that glucagon stimulates insulin release mainly through glucagon receptors but not GLP-1 receptors on islet beta cells. [Diabetologia (1995) 38: 274-276]

Key words Glucagon, insulin secretion, exendin (939), GLP-1, pancreas perfusion.
Glucagon stimulates insulin secretion from islet beta cells although its physiologic significance is not yet clear [1]. As a mechanism of this action, it had been generally accepted that insulin secretion is stimulated by glucagon directly through its own receptor on the beta cell, because specific binding sites of ${ }^{125} \mathrm{I}$-glucagon have been demonstrated in hamster beta-cell tumours [2] and purified beta cells [3]. Since then however, a proglucagon gene product, glucagon-like peptide-1 (7-36) amide/(7-37) (GLP-1), was shown to stimulate insulin secretion more potently $[4,5]$, and has been accepted as a physiologic insulin secretagogue; a candidate for incretin [6]. Specific receptors for GLP-1 have been detected on rat, mouse, and hamster insulinoma cell lines [7-9], and it is bound by glucagon with an affinity 100 to 1000 times lower than GLP-1 $[7,8]$. The insulinotropic activity

Received: 2 June 1994 and in revised form: 30 August 1994

Corresponding author: Dr. K. Kawai, Institute of Clinical Medicine, University of Tsukuba, Tsukuba, Ibaraki-ken 305, Japan Abbreviations: GLP-1, Glucagon-like peptide-1; BSA, bovine serum albumin; IRI, immunoreactive insulin. of glucagon is less potent than that of GLP-1 in the same order [10], leading to the hypothesis that glucagon exhibits its insulinotropic activity through GLP1 receptors but not glucagon receptors on islet beta cells [11]. Recently, it has been shown that exendin (9-39) amide is a potent receptor antagonist of GLP-1 $[12,13]$. In this study, we examined the effects of exendin (9-39) amide on GLP-1 or glucagonstimulated insulin release from isolated perfused rat pancreas in order to clarify whether or not glucagon stimulates the insulin release through its own receptor.

\section{Materials and methods}

Chemicals. Glucagon, GLP-1 (7-36) amide (GLP-1) and exendin (9-39) amide (exendin (9-39)) were synthesized by the stepwise solid-phase method using an automatic synthesizer (model 430A, Applied Biosystem, Foster City, Calif., USA), and then purified by high-performance liquid chromatography (HPLC). The purity of peptides was monitored by analytical reverse-phase HPLC on a column of Nucleosil 5C-18 (4.6× $150 \mathrm{~mm}$; GL Sciences, Tokyo, Japan) under the isocratic conditions of $0.1 \%$ trifluoroacetic acid and $39 \%$ acetonitril, and proved to be at least $98 \%$ pure [14]. 

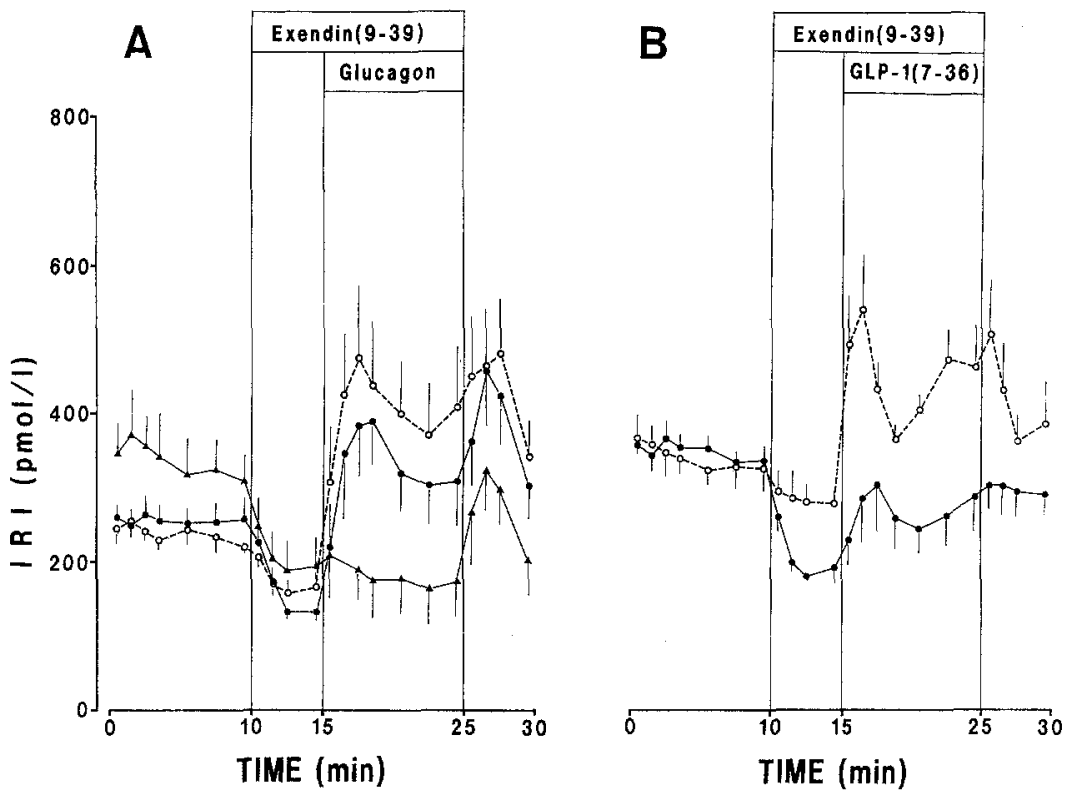

Fig. 1. A Effects of $100 \mathrm{nmol} / \mathrm{l}$ exendin (9-39) on basal insulin (IRI) release $(\boldsymbol{\Lambda}, n=5)$ and $1 \mathrm{nmol} / \mathrm{l}$ glucagon-stimulated insulin release $(\bullet, n=5$ ) from the isolated perfused rat pancreas. Control study o---o; 1 nmol/1 glucagon-stimulated insulin release during the vehicle infusion $(0.9 \% \mathrm{NaCl}$ containing $0.2 \% \mathrm{BSA}$, $n=5$ ).

B Effects of $100 \mathrm{nmol} / \mathrm{l}$ exendin (9-39) on $0.3 \mathrm{nmol} / \mathrm{l}$ GLP-1-stimulated insulin release $(\bullet, n=6$ ) from the isolated perfused rat pancreas. Control study $0 \cdots-\cdots(n=6)$. Results are means \pm SEM

Rat pancreas perfusion. The pancreas was isolated in male Wistar rats, weighing 300-350 g, under pentobarbital anaesthesia after an overnight fast. All rats were housed in a windowless, air-controlled room $\left(22 \pm 2^{\circ} \mathrm{C}\right)$ under a 12-h light $(08.00$ 20.00 ) hours/12-h dark cycle, and fed standard rat chow and water ad libitum. Perfusion was carried out according to the method of Grodsky et al. [15]. A Krebs-Ringer bicarbonate buffer solution containing $4 \%$ dextran T-70 (Pharmacia Fine Chemicals, Uppsala, Sweden), $0.2 \%$ bovine serum albumin (BSA), $5 \mathrm{mmol} / \mathrm{l}$ each of pyruvate, fumarate, glutamate and arginine, and $5.5 \mathrm{mmol} / 1$ glucose was equilibrated with a $95 \%$ $\mathrm{O}_{2}-5 \% \mathrm{CO}_{2}$ mixture at $37^{\circ} \mathrm{C}$, and then continuously gassed throughout the experiment. The pancreas was perfused from the celiac artery at a flow rate of $2 \mathrm{ml} / \mathrm{min}$. After $25 \mathrm{~min}$ of equilibration, the effluent perfusate was collected at 1 -min intervals by a cannula inserted into the portal vein. There was an initial basal period of $10 \mathrm{~min}$, and then exendin (9-39) dissolved in $0.9 \% \mathrm{NaCl}$ solution containing $0.2 \%$ BSA was administered for $15 \mathrm{~min}$ through a side-arm syringe at a rate of $0.1 \mathrm{ml} / \mathrm{min}$. Beginning $5 \mathrm{~min}$ later, glucagon or GLP-1 dissolved in $0.9 \% \mathrm{NaCl}$ containing $0.2 \% \mathrm{BSA}, 5 \mathrm{mmol} / \mathrm{l}$ arginine and $5.5 \mathrm{mmol} / 1$ glucose was infused for $10 \mathrm{~min}$ through another side-arm syringe at a rate of $0.1 \mathrm{ml} / \mathrm{min}$.

Assay. Immunoreactive insulin (IRI) was determined by RIA according to the method of Herbert et al. [16].

\section{Statistical analysis}

The degree of stimulation of insulin release initiated by the peptides was calculated as areas under the curve [14] and compared by Student's $t$-test for unpaired data. $p<0.05$ was considered significant, and all data are expressed as means \pm SEM.

\section{Results}

As shown in Figure $1 \mathrm{~A}, 100 \mathrm{nmol} / 1$ exendin (9-39) inhibited insulin release; the percent decrease in $\Sigma \Delta$ IRI from the preceding basal level was $40.3 \pm 3.6 \%$ $(n=5)$, which is significantly lower than that of the control experiment (infusion of the vehicle; $0.9 \%$ $\mathrm{NaCl}$ containing $0.2 \%$ BSA, data not shown); $25.1 \pm 5.3 \%(n=7, p<0.01)$. The infusion of $1 \mathrm{nmol} /$ 1 glucagon for $10 \mathrm{~min}$ during $100 \mathrm{nmol} / \mathrm{l}$ exendin $(9$ 39 ) infusion caused an increase in insulin release similar to the increase caused by $1 \mathrm{nmol} / \mathrm{l}$ glucagon during the vehicle infusion; the degree of increase in $\Sigma \Delta$ IRI from the preceding basal level (mean of 13and 15-min values) during the exendin (9-39) infusion was $93.1 \pm 9.6 \%$ compared to that of the control study.

On the other hand, insulin release caused by $0.3 \mathrm{nmol} / 1 \mathrm{GLP}-1$ during the $100 \mathrm{nmol} / 1$ exendin $(9-$ 39) infusion was clearly less than that caused by $0.3 \mathrm{nmol} / \mathrm{l}$ GLP-1 during the vehicle infusion (Fig.1B); the degree of increase in $\Sigma \Delta I R I$ from the preceding basal level (mean of 13- and 15-min values) during the exendin (9-39) infusion was $45.3 \pm 3.7 \%$ compared to that of the control study.

\section{Discussion}

In the present study, an antagonist of GLP-1, exendin (9-39), clearly inhibited $0.3 \mathrm{nmol} / \mathrm{l}$ GLP-1-induced insulin release, but elicited no significant effects on $1 \mathrm{nmol} / \mathrm{l}$ glucagon-induced insulin release from the isolated perfused rat pancreas. These results indicate that glucagon stimulates insulin release mainly through glucagon receptors but not GLP-1 receptors on islet beta cells. In other words, if there were no glucagon receptors on beta cells [17] and glucagon stimulates insulin release through GLP-1 receptors, the insulin release caused by $1 \mathrm{nmol} / 1$ glucagon should be inhibited more clearly than that by $0.3 \mathrm{nmol} / \mathrm{l}$ GLP-1. A similar result has been reported in an in 
vivo study using fasted dogs [18]. In our direct comparison of the insulinotropic activity of glucagon superfamily-peptides, the half-maximum effective dose $\left(E D_{50}\right)$ for glucagon was 25 times greater than that for GLP-1 (2.7 nmol/1 and $50 \mathrm{pmol} / 1$, respectively) [19], while the binding of ${ }^{125}$ I-GLP-1 to GLP-1 receptor-transfected COS cells was inhibited to only $50 \%$ by $1 \mu \mathrm{mol} / 1$ glucagon [20]. These results also support the conclusion of the present study.

In this study, $100 \mathrm{nmol} / 1$ exendin (9-39) itself inhibited insulin release. This inhibition has been found to be dose dependent (unpublished observation). This suggests that beta-cell GLP-1 receptors in this study may in some way be activated leading to elevated basal insulin release which could then be counteracted by the antagonist. Alternatively, exendin (9-39) might modulate insulin release through other direct or indirect mechanisms. It will be interesting to study this in the future.

Acknowledgements. The authors wish to thank Ms. K. Sasaki for her excellent technical assistance. This study was supported by a grant from the University of Tsukuba Research Project.

\section{References}

1. Samols E, Marris G, Marks V (1965) Promotion of insulin secretion by glucagon. Lancet 2: 415-417

2. Goldfine ID, Roth J, Birnbaumer L (1972) Glucagon receptors in $\beta$-cells: binding of ${ }^{125}$ I-glucagon and activation of adenylate cyclase. J Biol Chem 247: 1211-1218

3. Van Schravendijk CFH, Foriers A, Hooghe-Peters EL et al. (1985) Pancreatic hormone receptors on islet cells. Endocrinology 117: 841-848

4. Holst JJ, Ørskov C, Nielsen OV et al. (1987) Truncated glucagon-like peptide-I: an insulin-releasing hormone from the distal gut. FEBS Lett 211: 169-174

5. Mojsov S, Weir GC, Habener JF (1987) Insulinotropin: glucagon-like peptide I (7-37) actions on endocrine pancreas. J Clin Invest 79: 616-619

6. Creutzfeldt W, Nauck M (1992) Gut hormones and diabetes mellitus. Diab Metab Rev 8: 149-177

7. Ørskov C, Nielsen JH (1988) Truncated glucagon-like peptide-1 (proglucagon 78-107 amide), an intestinal insulin-re- leasing peptide, has specific receptors on rat insulinoma cells (RIN 5 AH). FEBS Lett 229: 175-179

8. Fehmann HC, Habener JF (1991) Functional receptors for the insulinotropic hormone glucagon-like peptide-1 (7-37) on a somatostatin secreting cell line. FEBS Lett 279: 335 340

9. Fehmann HC, Habener JF (1991) Homologous desensitization of the insulinotropic glucagon-like peptide-I (7-37) receptor on insulinoma (HIT-T15) cells. Endocrinology 128: 2880-2888

10. Weir GC, Mojsov S, Hendrick GK et al (1989) Glucagonlike peptide I (7-37) actions on endocrine pancreas. Diabetes 38: 338-342

11. Fehmann H-C, Göke R, Göke B (1992) Glucagon-like peptide-1 (7-37)/(7-36) amide is a new incretin. Mole Cell Endocrinol 85: C39-C44

12. Raufman J-P, Singh L, Singh G et al. (1992) Truncated glucagon-like peptide- 1 interacts with exendin receptors on dispersed acini from guinea pig pancreas. J Biol Chem 267: 21432-21437

13. Göke R, Fehmann H-C, Linn Tet al. (1993) Exendin-4 is a high potency agonist and truncated exendin-(9-39)-amide an antagonist at the glucagon-like peptide 1-(7-36)-amide receptor of insulin-secreting $\beta$-cells. J Biol Chem 268: 19650-19655

14. Kawai K, Suzuki S, Ohashi S et al. (1989) Comparison of the effects of glucagon-like peptide-1 (1-37) and -(7-37) and glucagon on islet hormone release from isolated perfused canine pancreas. Endocrinology 124: 1768-1773

15. Grodsky GM, Batts AA, Bennett LL et al. (1963) Effects of carbohydrates on secretion of insulin from isolated rat pancreas. Am J Physiol 205: 638-644

16. Herbert V, Lau KS, Gottlieb CW et al. (1965) Coated charcoal immunoassay of insulin. J Clin Endocrinol Metab 25: 1375-1384

17. Kofod H, Adelhorst K, Christensen LB et al. (1993) Betacells do not have glucagon receptors but GLP-1 receptors. Digestion 54: 346-347

18. Eng J, Gutterman V, Nicolis C (1993) Exendin (9-39) amide inhibits the insulin secretagogue activity of exending 4 and GLP-1 but enhanced that of glucagon in dogs. Digestion 54: 354

19. Suzuki S, Kawai K, Ohashi S et al. (1992) Comparison of the insulinotropic activity of glucagon-superfamily peptides in rat pancreas perfusion. Horm Metab Res 24: 458461

20. Thorens B (1992) Expression cloning of the pancreatic $\beta$ cell receptor for the gluco-incretin hormone glucagon-like peptide-1. Proc Natl Acad Sci USA 89: 8641-8645 